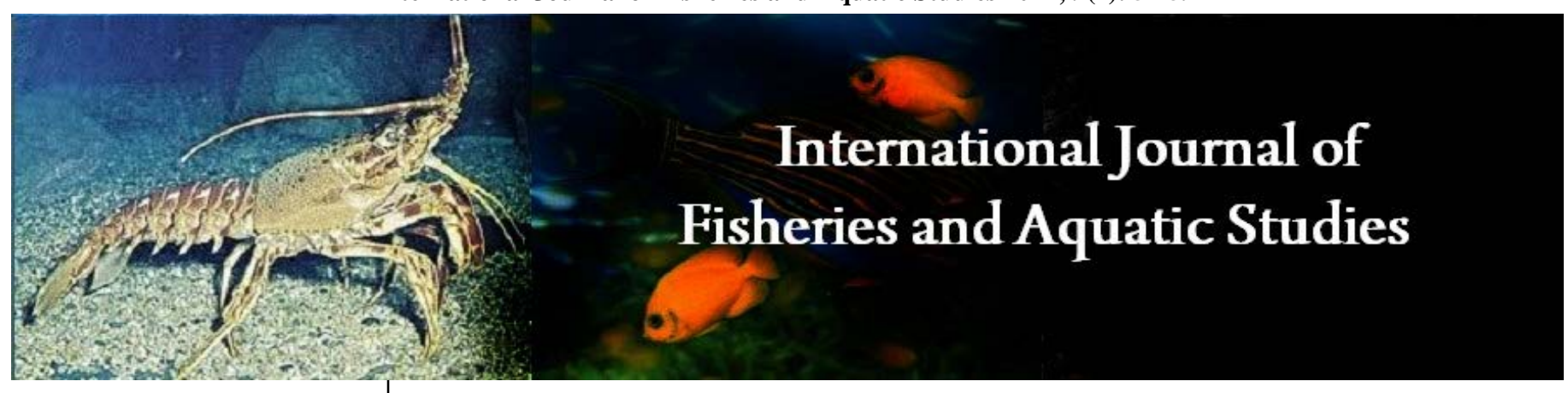

E-ISSN: 2347-5129

P-ISSN: 2394-0506

(ICV-Poland) Impact Value: 5.62

(GIF) Impact Factor: 0.549

IJFAS 2021; 9(2): $52-59$

(C) 2021 IJFAS

www.fisheriesjournal.com

Received: 24-01-2021

Accepted: 26-02-2021

\section{Alexander Dunbar}

National Fisheries and

Aquaculture Authority,

Monrovia, Liberia

\section{David Mungai}

Wangari Maathai Institute for

Peace and Environmental

Studies, University of Nairobi,

Nairobi, Kenya

\section{John Kaunga Muthee}

Department of Clinical Studies,

University of Nairobi, Nairobi, Kenya
Corresponding Author: Alexander Dunbar

National Fisheries and

Aquaculture Authority,

Monrovia, Liberia

\section{Factors influencing the sustainable utilization of artisanal fisheries: A case of west point, Liberia}

\author{
Alexander Dunbar, David Mungai and John Kaunga Muthee
}

DOI: https://doi.org/10.22271/fish.2021.v9.i2a.2442

\begin{abstract}
Self-governance in which local actors can communicate and develop rules of reciprocity leads to sustainable utilization of resources such as fisheries. This study uses a Social-Ecological System approach to investigate the self-organized informal governance regime of the artisanal fisheries in West Point, Liberia. A slum community of 1249 full-time fishermen. The population was stratified according to fishing methods and a sample size of 303 fishermen was randomly selected using a proportion allocation method and data was analysed using descriptive statistics. Findings showed that current catch assessment and fishing effort represent only $4 \%$ of the actual production of the artisanal fishery in Liberia. The study also revealed that the self-governing regime doesn't regulate gears and methods. Rules developed are mainly social-economic. Environmental rules that protect the resource base are lacking. Factors influencing the sustainable use of the artisanal fisheries also included the use of beach seine, monofilament nets, $41.6 \%$, and monofilament lines, $11.2 \%$. Other factors were conflicts and the sources of conflict identified as competition for the same fish species and fishing grounds. The study concludes that tailoring rules that protect the resource base into the self-governance regime will lead to the sustainability of the resource system.
\end{abstract}

Keywords: Sustainable utilization, artisanal fisheries, west point, Liberia

\section{Introduction}

Fisheries are the primary source of protein for over 1 billion people globally ${ }^{[1]}$ and play an important role in the economies of many coastal and developing countries ${ }^{[2]}$. It's the world's most widely traded food product with an international seafood trade value of about \$141.6 billion ${ }^{[3]}$ more than half of it from the artisanal fisheries ${ }^{[4]}$. Artisanal fishing and fish farming account for about $90 \%$ of the world fisheries' jobs ${ }^{[5]}$. This multispecies subsector employs more people and poses less environmental problems compared to the industrial sector ${ }^{[6]}$, [7] Governing these common resources present social and ecological opportunities and challenges in the form of resource abundance, strong market and dynamic climate ${ }^{[7]}$. The artisanal fisheries in Liberia are open access managed under a self-organized informal management system headed by a sea chief. The chief is responsible to bring together all stakeholders to discuss issues of common concern. Open resources are prone to rivalry, non-excludability of

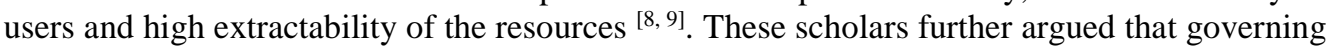
the commons (e.g., fisheries) should include a focus on biophysical characteristics such as production of the resource system, attributes of fishermen, and the self-organized governance system. A case at this point is the artisanal fisheries in Liberia. Thus these fisheries are prone to unsustainable utilization and depletion of fish stock ${ }^{[10]}$. Recognizing those important social factors that influence adaptive capacity of artisanal fisheries reduces vulnerability to external shocks ${ }^{[7]}$. This study is therefore justified at establishing the status of the artisanal fisheries and identifying those factors that are influencing their sustainable utilization.

\section{Theoretical basis and conceptual framework}

\subsection{Governing the commons}

Over the past fifty years, global fish production has increased, outpacing the rate of population growth, 3.5\%-1.6\% respectively ${ }^{[11]}$. Percapita consumption also increased at an average rate of $1.5 \%$ during the same period from $9.0 \mathrm{~kg}$ to $20.2 \mathrm{~kg}$. 
This means that the need for fish is fast-growing exceeding the rate of population growth ${ }^{[11,12]}$ at the same time global fish production is declining and most oceans depleting ${ }^{[13]}$. The researcher also reported that at least $70 \%$ of world fisheries have been fully exploited, overexploited or recovering from depletion. Governance and sustainable utilization of these resources will ensure food security and maintain the supply of fish protein to dependent countries. As global population increases, the fight for natural resources will increase resulting in overuse and resource collapse ${ }^{[14]}$. Fisheries governance, national and international policies and legal frameworks will ensure sustainable harvest ${ }^{[15]}$.

There are many literature streams focusing on governing artisanal fisheries as a common resource and stressing on factors influencing the sustainable utilization of these fisheries. For instance, the most famous governance theory of common-pool resources is Hardin (1968) ${ }^{[9]}$, who said that the tragedy of the commons is characterized by high extractability of resources and low excludability of users mainly due to the lack of property rights and that this tragedy can be averted through nationalization and privatization or cohesive laws and taxes. Hardin, (1968) ${ }^{[9]}$ concept was focused on open access resources where there is a race for a resource. Fisheries that experience overfishing from common property and open access should implement collaborative resource management to avoid the dominance of one party. Hence, collective action to sustainably use natural resources can avert resource collapse ${ }^{[14,16]}$. A study by Hawkshaw, and Sumaila (2012) ${ }^{[17]}$ that analyses Hardin (1968) ${ }^{[9]}$ reported that for resources such as fisheries, a tragedy can be prevented through taxation and regulation and not common property rights. Therefore, we can conclude that the sustainable use of artisanal fisheries is influenced by governance factors. Nonetheless, Despite the vulnerability of the open-access of the artisanal fisheries in Liberia, there exist limited studies that unravel the effectiveness of the self-organized governance system. Therefore, this study assesses the self-organized informal governance of the artisanal fisheries in Liberia by identifying those factors that are influencing the sustainable utilization of the resources.

An Alternative approach to governing the commons was proposed ${ }^{[18,19]}$. This approach highlights how the tragedy of small-scale common-pool resources are overcome through self-organizing and self-governing of communities with no government or market interventions. This is done if these communities can communicate, and develop norms and rules of reciprocity to govern their resource ${ }^{[19,20]}$. The researchers also highlighted the polycentrism of resource governance. This framework is useful in understanding the influence of formal and informal institutions, state and non-state actors, the nature of multi-level interactions, bureaucratic hierarchies, and markets ${ }^{[21]}$. This also provides an analytical framework in the form of Ostrom (2009) ${ }^{[19]}$ Social-Ecological System Framework where multiple actors or centres of decision making establish collaboration or in an informal commitment to address common problems through self-governance ${ }^{[22]}$. Though the researcher reported structural inequalities, and lack of coordination among actors as failures of polycentric governance, Parente and Pessoa (2009) ${ }^{[23]}$ expounded that the framework promotes sustainable development, economic competitiveness, and social cohesion.

\subsection{Conceptual framework}

In conclusion, the objective of the study was achieved by analysing the artisanal fisheries in Liberia as a complex social-ecological system [6, 16, 19, 24, 25]. The approach investigated the artisanal fisheries as a resource system (Figure 1) and how fishermen attributes, their self-governance system and the biophysical characteristics of the resource system affect its sustainability ${ }^{[22]}$. This concept contributes to understanding the feedback of chance in the artisanal fisheries to the behaviour of fishermen (and vice versa) allowing us to study several aspects of the fisheries. The framework looks into how fishermen (resource users) extract different types of fish species (resource units) from the artisanal fishery (resource system) and how these users maintain the sustainability of the resource system through a self-organised system and rules (overarching Governance system) ${ }^{[26]}$.

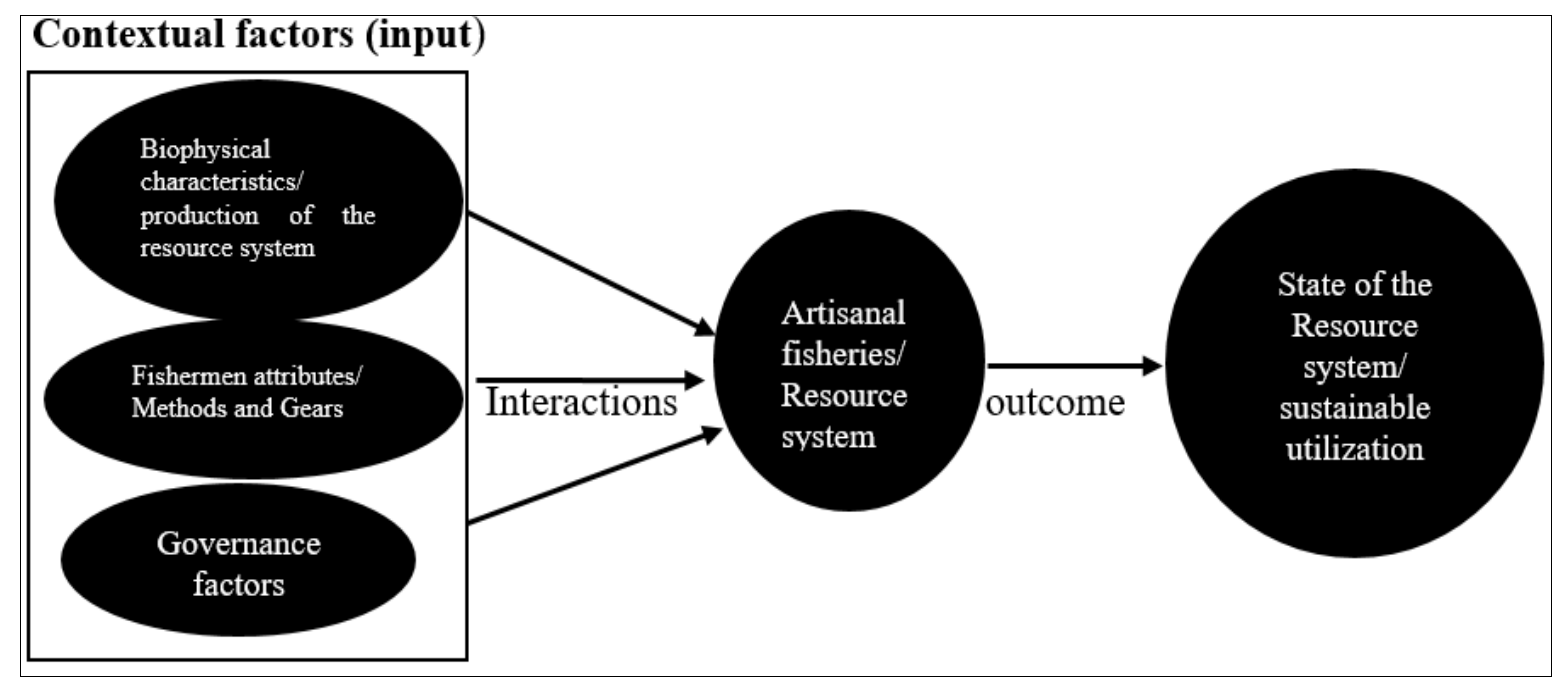

Fig 1: Conceptual Framework 


\section{Materials and Methods 3.1 The study area}

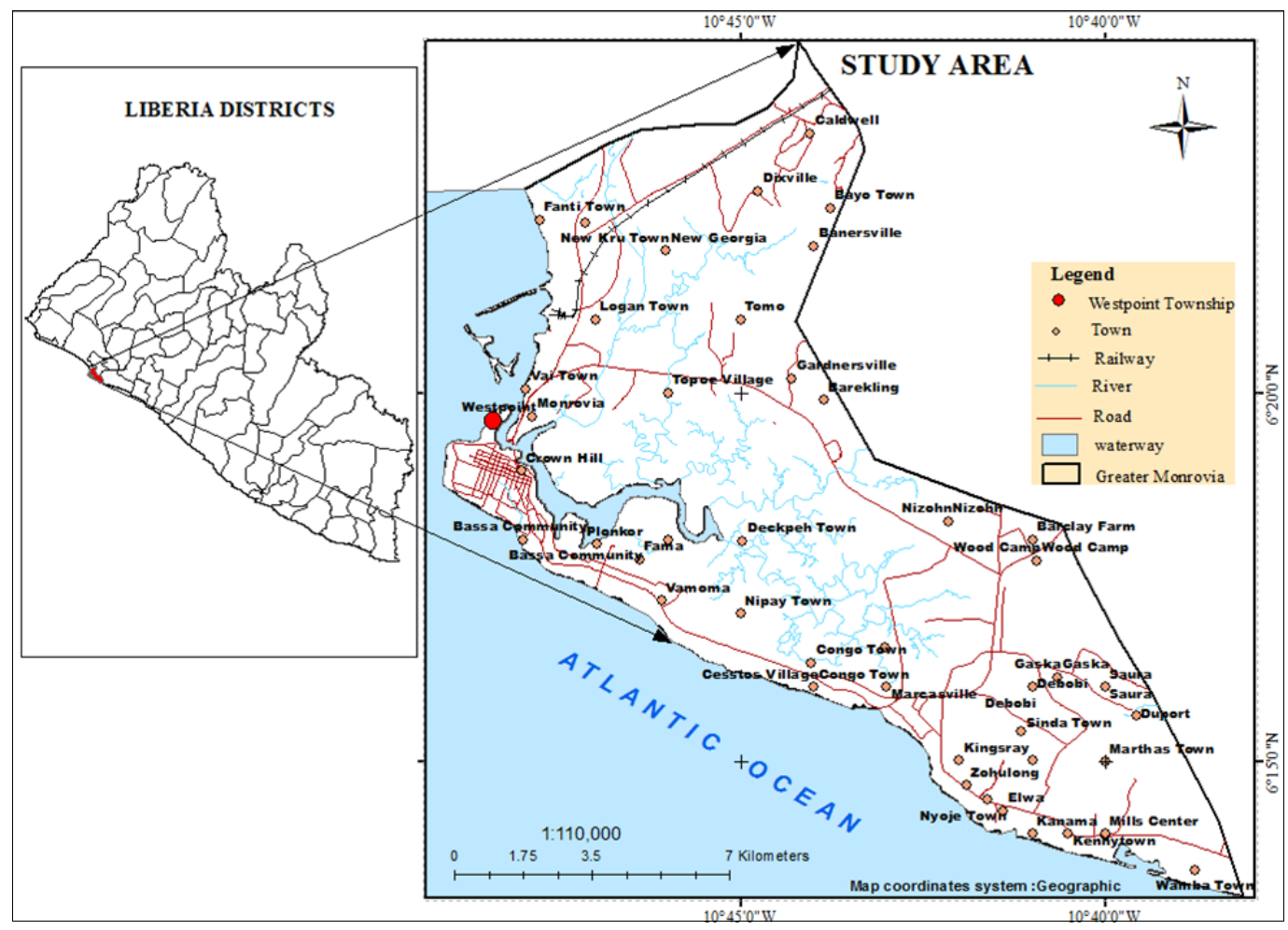

Fig 2: The Study Area

The study was conducted in Westpoint (figure 2), Liberia, a slum township community next to Monrovia city centre with two fishing communities (Kru town and Fanti town) and a geographical coordinate as $6.3265^{\circ} \mathrm{N}, 10.8081^{\circ} \mathrm{W}$. With a population of 1249 full-time fishermen, West Point is the biggest fishing community in Liberia. It lies between the St. Paul and the Mesurado rivers jutting out into the Atlantic Ocean. The Mesurado River separates West Point from Bushrod and the providence islands. Fishing and related activities such as fish processing are the primary sources of livelihood for the residents of West Point.

\subsection{Data collection}

The study employed descriptive research designed that took case study, survey methods and a secondary data complemented by a fish weight sampling. In order to fully understand the self-organized local governance of the artisan fishers and how their attributes influence the sustainable use of the resource, the study first employed a scoping study with two trained research assistants and a research guide who were all familiar with the study area. A checklist was prepared in the form of a Social-Ecological Inventory ${ }^{[27]}$ to map key players and their knowledge of west point artisanal fisheries, fishing practices, and existing governance structure. This exercise allowed us to test and made adjustments to the questionnaire and selected key informants through a preinterview screening at which point a formal interview was set up for data purposes.

\subsubsection{Sampling}

The sampling frame for the questionnaire was differentiated by the four methods of fishing in the two fishing communities of West Point. This tool was designed to gather data on how the fishermen are self-governed and how this influences the use of the resource. The sample size was determined using:

$$
\begin{aligned}
& n=\frac{N}{1+N\left(e^{2}\right)}, \text { where } n=\text { sample size, } N=\text { Population. } \\
& e=\text { Error }^{[28,29]} \\
& n=\frac{1249}{1+1249\left(0.05^{2}\right)} \\
& n=303 \text { Artisanal fishermen }
\end{aligned}
$$

The sample size was stratified based on fishing methods (Table: 1). The researchers aimed at ensuring equal stratification and distribution of the population to present equal observation of every stratum [30, 31]. A proportion allocation was used to determine the appropriate sample from each stratum in the various fishing communities utilizingutilizing

$$
n_{i}=n\left(\frac{N_{i}}{N}\right)^{[32]}
$$

Where $n_{i}=$ sample size per landing site, $n=$ sample size selected from the population, $N_{i}=$ population of the $i^{\text {th }}$ strata per landing site, $N=$ accessible population of the study.

$$
n_{i}=303\left(\frac{916}{1249}\right)
$$

$n_{i}=222$ sample size from fanti town

$$
n_{i}=303\left(\frac{333}{1249}\right)
$$


$n_{i}=81$ Sample size from Kru town

Table 1: Sample size distribution according to fishing methods

\begin{tabular}{|c|c|c|c|c|}
\hline \multicolumn{2}{|c|}{ Kru town } & \multicolumn{2}{c|}{ Fanti town } \\
\hline Methods of fishing & Population & sample size Population & sample size \\
\hline Ring net & 0 & 0 & 447 & 108 \\
\hline set net & 128 & 31 & 469 & 114 \\
\hline Beach seine & 66 & 16 & 0 & 0 \\
\hline Hooks and line & 139 & 34 & 0 & 0 \\
\hline Subtotal & 333 & 81 & 916 & 222 \\
\hline
\end{tabular}

\subsubsection{Fish weight sampling}

Understanding the status of the fisheries is important to observe its changes over time. Catch reports from the erstwhile Bureau of National Fisheries between 2013 and 2014 was incomplete in weight. Species are measured informally using Tub, Bucket, Bag, Bunch, Piece, and hand disregarding the weight of these units. Year to year catch report is measured in these units with most species having no corresponding weights. A species weight sampling was conducted on species without weight. All the informal weight measurements were now converted into a single unit (tons).

\subsubsection{Interviews}

A pretested questionnaire was administered to 303 fishermen to gather data on fishing methods and gears and local governance regime that influence the sustainability of the resource system. The study sort to minimized errors and increase confidence and reliability in the data captured. Hence, The researchers filled out questionnaire for respondents who were illiterate to avoid respondents not responding to questions ${ }^{[33]}$.

Additionally, key informants were identified from the Social Ecological Inventory and two Focus Group Discussions of ten participants were carried out in the two fishing communities of West Point. Participants discussed and deliberated openly, new insights and different views were recorded on the components of the conceptual framework.

\section{Results}

\subsection{Descriptive statistics}

Respondents were sampled from the various landing sites in the two fishing communities of West Point with 81 fishermen from Kru Town and 222 fishermen from Fanti Town (Table:1). Fanti Town had a proportionately larger sample compared to Kru Town. The results showed that all the respondents from the fishing communities (100\%) were men. findings showed that the participation of women in the fisheries' value chain is mainly in post-harvest handling as fishmongers and processors. The study further showed that fishing was practised by a relatively large proportion (57.1\%) of fishermen below thirty-five years of age. The mean age of fishermen interviewed was $34 \pm 10.29$ years in both Kru Town and Fanti Towns. Out of those interviewed, 49.2\% have no formal education. The study further revealed a significant difference in education with $58 \%$ of Fanti having no form of education compared to $25 \%$ of Kru. Majority of the fishermen (23.4\%) have their highest level of education attained as secondary school.

\subsection{Local governance}

Key informants confirmed that the artisanal fisheries are open access managed under a self-organized informal management system headed by a sea chief. Findings also showed minimum coordination among local actors. The study sought to identify rules and conflict within the local governance system. Results (Figure:3) showed nine rules that are commonly mentioned. These are mainly social-economic rules emphasizing the wellbeing of the artisan fishers. Some key informants mentioned rules such as no chemical fishing, locate and retrieve lost nets as rules for the sustainable use of the fisheries. Respondents (48.1\%) mentioned No fighting at sea as the most important rule followed by No smoking (14.9\%). Findings further revealed that the rule of no smoking is intended to deter fishermen from the use of drugs such as marijuana. The Fanti dominance in the subsector creates limited competition with the Kru fishermen.

The sources of conflict within the Liberian artisanal fisheries are competition for same fish species (ilisha Africana )and fishing grounds, and methods of fishing, others included stealing of fishing materials and fish at sea, the lack of coordination among elders and local actors and national rules that contravene fishermen livelihood objectives; hence, fishermen livelihood depends on daily fishing. National holidays adapted by the self-governance system impede their daily fishing activities.

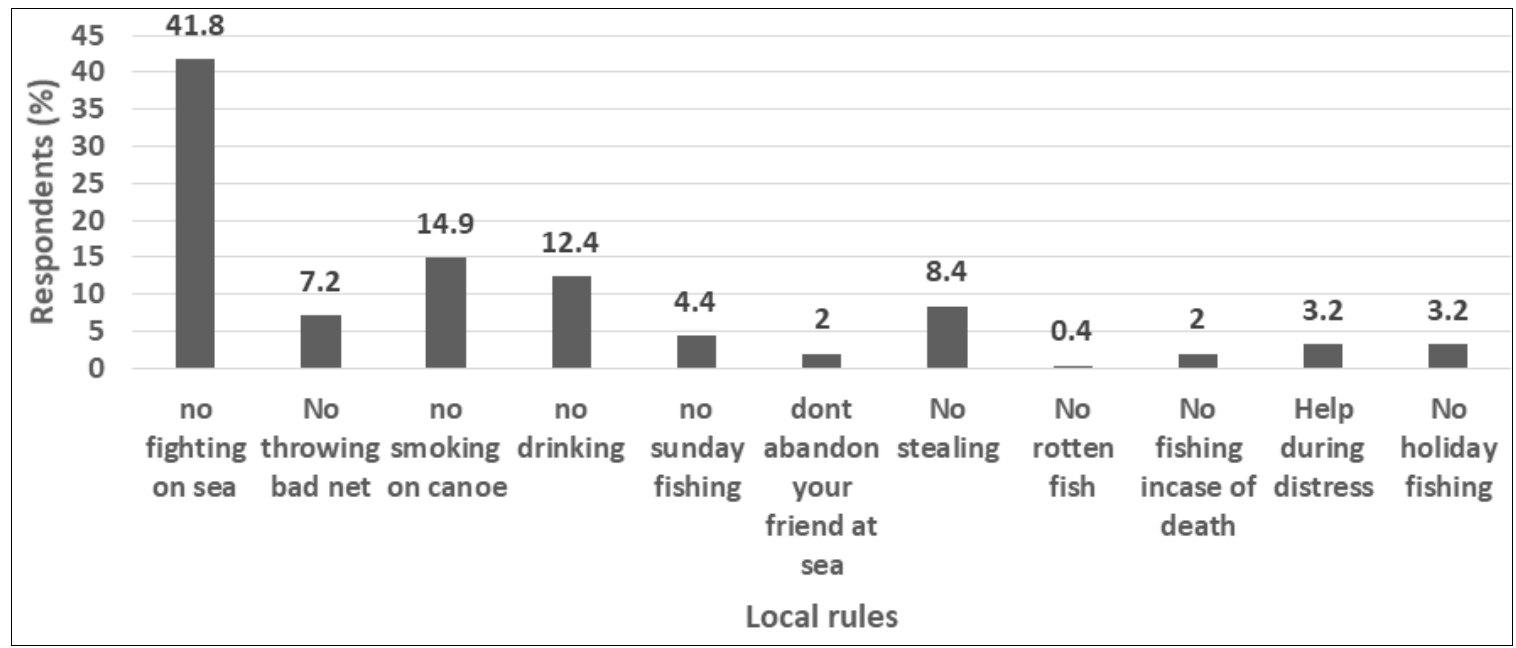

Fig 2: Local rules from the self-organized governance system 


\subsection{Status of the artisanal fisheries in Liberia} 4.2.1 Yield of the artisanal fisheries in Liberia 2013-2014

The research failed to establish the trend of the artisanal fisheries not only due to the lack of time-series data but also because of inadequate assessment of fishing effort or catch statistics. However, a two-year (2013-2014) production of the subsector was established (Figure:4) from data from the erstwhile Bureau of National Fisheries and the study. Results revealed that the total production of the artisanal fisheries was 57,137.34 and 33,338.37 tons in 2013 and 2014 respectively. This shows a $41.7 \%$ decrease in total production within the two years. Data also revealed that $63 \%$ of total fish harvested during this period was in 2013 alone and 37\% in 2014 with a year-to-year average catch per canoe as 15 and 8.7 tons in 2013 and 2014 respectively. Key informants acknowledged the huge drop in production and attributed it to the lack of funding to conduct catch assessment and fishing effort and that the drop did not reflect the biological productivity of the resource system. A reliability assessment revealed that there are twenty-four sampling stations to conduct catch assessment representing $21 \%$ of the total landing sites in the country. Seven canoes are sampled at each sampling station representing $4.42 \%$ of the artisanal vessels in Liberia. This implies that the artisanal fleets are under-represented and catches are grossly underestimated. Data also shows (Figure 5) that of the quantity of fish harvested in the two years, the most commercialized fish species was Sidenella Maderensis constituting $87.89 \%$ and $72.7 \%$ of total fish harvested in 2013 and 2014 respectively followed by Pseudotolithus senegalensis 3.93\% in 2013 and Chloroscombrus chrysurus $12.89 \%$ in 2014.

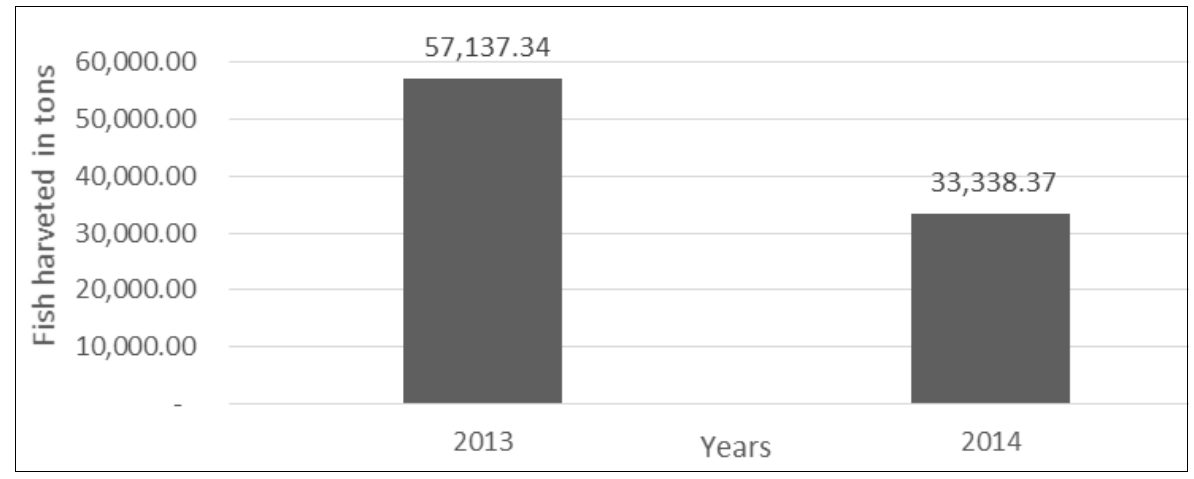

Fig 3: yield of the artisanal fisheries, 2013 and 2014

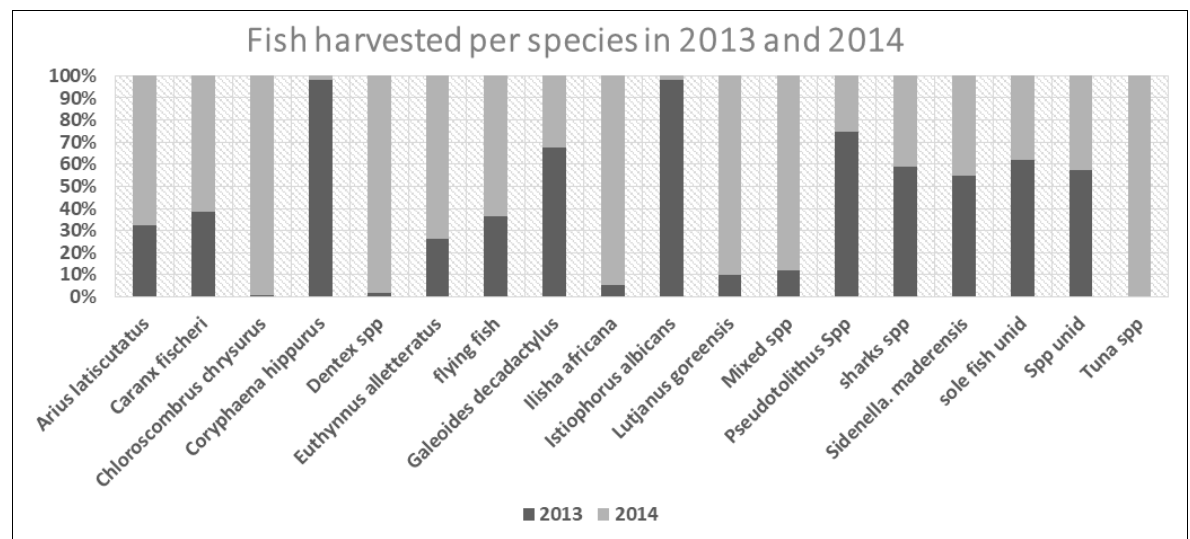

Fig 4: Rate of harvest of most commercialized species

\subsubsection{Preservation}

Preservation plays major role in reducing physical and economic losses and reducing pressure on the resource base. The study showed that of those surveyed, $90.4 \%$ have no form of preservation, and only $7.9 \%$ use ice at sea to preserve their catches (Table: 2). Compared to the Fanti fishermen, a huge proportion of the Kru (94\%) do not use any form of preservation. The common method of preserving fish at sea is the application of ice on the catches, which is practiced by $11 \%$ of Fanti fishermen. Findings also revealed that $1.7 \%$ of respondents or $6 \%$ of Kru fishermen use wooden covers. These wooden covers reduce the sun from directly hitting the fish thereby delaying deterioration.

Table 2: Methods and levels of preservation

\begin{tabular}{|c|c|c|c|c|c|c|}
\hline & \multicolumn{2}{|c|}{ Kru town } & \multicolumn{2}{c|}{ Fanti town } & & \\
\hline Methods of preservation & Frequency & percent & Frequency & Percent & Overall Frequency & Overall Percent \\
\hline No preservation & 76 & $94 \%$ & 198 & $89 \%$ & 274 & $90.40 \%$ \\
\hline Ice & 0 & $0 \%$ & 24 & $11 \%$ & 24 & $7.90 \%$ \\
\hline Wooden cover & 5 & $6 \%$ & 0 & $0 \%$ & 5 & $1.70 \%$ \\
\hline Total & 81 & $100 \%$ & 222 & $100 \%$ & 303 & $100 \%$ \\
\hline
\end{tabular}




\subsection{Evaluating methods and gears in terms of sustainable utilization of the artisanal fisheries}

\subsubsection{Methods of fishing and gear classification}

The study shows (Table: 3 ) four fishing methods being used in the study area. Beach seine represents $20 \%$ of all the fishing activities in Kru town. Hooks and line which is $100 \%$ practiced by Kru fishermen constitute $42 \%$ of all the fishing activities in Kru town and $11.2 \%$ of the overall fishing activities in West Point. Findings also showed ring net being practiced $100 \%$ by the Fantis and constituting $35.5 \%$ of the overall fishing activities in West Point.

The study also revealed (Table 4 ) that $41.6 \%$ of respondents used monofilament gill nets while $11.2 \%$ use monofilament lines. Results also showed that the monofilament lines are only used by the hooks and line fisher folks. The artisanal Kru fishermen prefer this gear due to its low-cost.

Table 3: Methods of fishing in West Point

\begin{tabular}{|c|c|c|c|c|c|c|}
\hline & \multicolumn{2}{|c|}{ Kru town } & \multicolumn{2}{c|}{ Fanti town } & & \\
\hline Methods of fishing & Frequency & Percent & Frequency & Percent & overall Frequency & overall percent \\
\hline Beach seine & 16 & $20 \%$ & 0 & $0 \%$ & 16 & 5.3 \\
\hline Set net & 31 & $38 \%$ & 114 & $51 \%$ & 145 & 47.9 \\
\hline Hook and line & 34 & $42 \%$ & 0 & $0 \%$ & 34 & 11.2 \\
\hline Ring net & 0 & $0 \%$ & 108 & $49 \%$ & 108 & 35.6 \\
\hline Total & 81 & $100 \%$ & 222 & $100 \%$ & 303 & 100 \\
\hline
\end{tabular}

Table 4: Gear classification

\begin{tabular}{|c|c|c|c|c|}
\hline & \multicolumn{2}{|c|}{ Fishing Community } & \multirow[b]{2}{*}{ Total } & \multirow[b]{2}{*}{ percent } \\
\hline Gears Classification & Kru town & Fanti town & & \\
\hline Mono filament gill net & 31 & 95 & 126 & $41.60 \%$ \\
\hline Multifilament net & 16 & 127 & 143 & $47.20 \%$ \\
\hline Monofilament gill line & 34 & 0 & 34 & $11.20 \%$ \\
\hline Total & 81 & 222 & 303 & $100 \%$ \\
\hline
\end{tabular}

\subsubsection{Mesh sizes of gears}

Fishermen measure mesh sizes of gears using their fingers.
One finger is equal to one inch. The study revealed (Figure 6) that meshes of gears ranged from 1 to5 inch with most fishermen doubling their fishing nets to further reduce the mesh. The study further shows that the highest mesh size of gear used by fishermen ranges from 1 inch (38.2\%) followed by 2 inches (15.3\%). The lowest meshes used in the study area range from 3.5 to 5 inches. This reveals that except the 4 inches mesh size nets which are used to target small pelagic species such as Istiophorus albicans, gears with bigger meshes are less likely to be used.

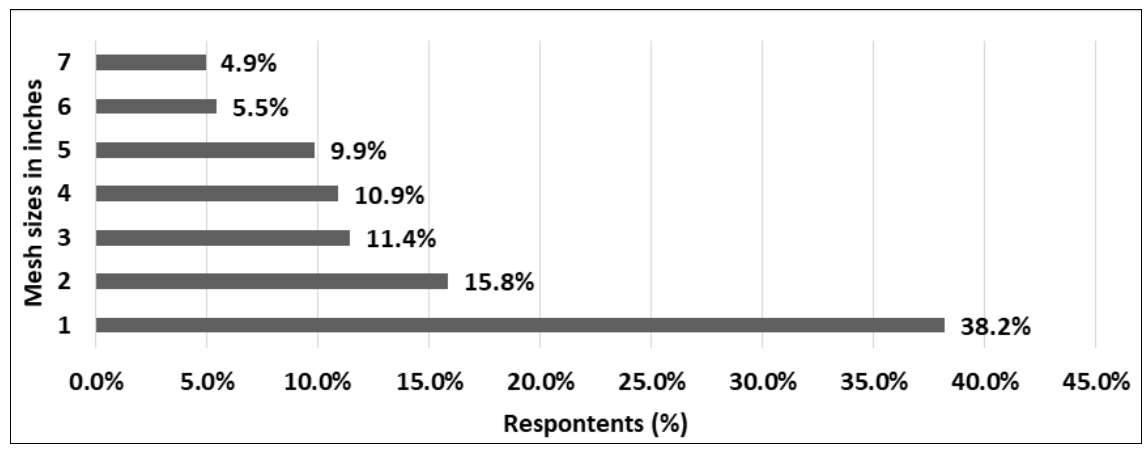

Fig 6: Mesh sizes of gears in West Point

\section{Discussion}

The sustainable utilization of the artisanal fisheries depends on the governance factors employed by the resource users for the use of the resources as a social-ecological system ${ }^{[34]}$. Social Economic attributes of fishermen either promote or undermine the sustainability of a resource system ${ }^{[34]}$. There is a significant difference in the role of men and women in

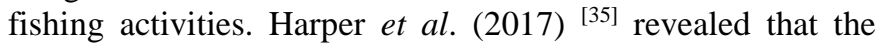
role of women in fish value chain grossly underestimated. The researcher discussed that men are directly involved in fishing while women are mainly post-harvest handling such as processing and preserving and that the unequal valuation of men and women contribution to fisheries was due to fisheries managers, researchers focus on direct fishing activities ignoring indirect activities where women are concentrated. The role of women is also underestimated in fisheries management and policy of the self-governance of local fishermen. Harper et al. (2013) ${ }^{\text {[36] }}$ reported that women represented $56 \%$ of annual small-scale catches in the Pacific resulting resulting in an economic impact of $\$ 110$ million in revenue.

The study contradicts Glasgow (2008) ${ }^{[37]}$ who reported an average catch per canoe of 2.2 and 1.16 tons in 2004 and 2005 respectively. Catch reports from the artisanal fisheries are underestimated confirming a study by Belhabib et al. (2013) [38]. Data from the artisanal fisheries submitted to FAO is $66 \%$ lower than the actual production of the subsector ${ }^{[39]}$. Adriat et al. (2011) ${ }^{[40]}$ Stressed the need for a long-term time-series data to correctly estimate the status of exploited resources and their development over time.

Fishermen from the Kru fisheries mostly use monofilament gillnets compare to the Fanti that commonly uses multifilament nets, Hence, the Fanti ring and set net methods of fishing only allow the use of multifilament gears. Key environmental impacts of these monofilament gears include ghost fishing ${ }^{[41]}$ of lost gears due to the non-degradability of the fibre, incidental catch of marine mammals, sea turtles, and sharks. The use of these gears also results in coral reefs entanglement; killing the reefs ${ }^{[42]}$. Increase in mesh size concurrently lead to the reduction of fishing mortality in smaller sized fish and reduction in mesh sizes increases catch rate of juvenile species ${ }^{[27-28]}$. Small mesh sizes select fish during a short time window of their life cycle and allow more spawners to remain in the stock. Of special case is that large 
spawners are particularly favoured by gillnets of smaller mesh sizes. This is because they cannot penetrate enough to be gilled; making them less vulnerable ${ }^{[45]}$.

Fish is highly susceptible to deterioration when not processed or preserved properly ${ }^{[46]}$. The researchers also reported that due to poor infrastructure and processing facilities, $40 \%$ of total catch by weight in Africa goes to spoilage. A certain percentage of fishermen catch by weight in Nigeria is lost due to inadequate infrastructure and processing facilities for postharvest handling ${ }^{[47]}$. An increase in preservation promotes sustainable utilization by reducing physical and economic losses and further decreasing the fishing intensity and pressure on the resource base.

An open-access self-governance regime like Liberia artisanal fisheries is prone to rivalry and conflict. Olomola (1998) ${ }^{[48]}$ reported that the sources of conflict within artisanal fisheries are competition for the same fish species and fishing grounds, and methods of fishing. These conflicts also serve as constraints to the sustainable use and development of the subsector ${ }^{[49]}$. Asare \& Okyere (2012); Ostrom (1990) ${ }^{[10,50]}$ also reported that common pool resources like the Liberian artisanal fisheries operating as an open-access regime increases high dependency and conflict and high rate of harvest leading to overexploitation. For a sustainable utilization of the commons, some tailored governance regime needs to be implemented in the form of access restriction to the resource and the provision of incentives for users ${ }^{[19,51]}$. The researchers also reported that these are achievable through social networks and rules of reciprocity ${ }^{[52]}$.

\section{Conclusions}

The study concludes that the use of artisanal fisheries through its self-organized informer governance regime is unsustainable. The self-governance system promotes sustainable use but weak in regulating fishing gears and methods and the development of rules of reciprocity that protect the resource base. Catch estimate and fishing efforts are grossly underestimated by the fisheries authority. There are also high, physical and economic losses due to the substantial level of low preservation of catches. While men are directly involved in fishing activities, the role of women in the value chain of fish is also significantly unrecorded. Additionally, the quantity of fish harvested from the artisanal fisheries that go to spoilage is unknown. Therefore, applying better and more successful measures for fishery resources protection, constant monitoring and assessment of the impact of fishing methods and gears on coastal fish and marine environments have to be performed, especially for fishing gears that are classified as harmful. Rules that protect the resource base need to be incorporated in the self-governance system, increase in preservation will reduce post-harvest losses and further reduce pressure on the resource base. There is also a need for gender mainstreaming and the role of each gender adequately recorded.

\section{Acknowledgement}

This study is based upon work supported by the United States Agency for International Development, as part of the Feed the Future initiative, under the CGIAR Fund, award number BFSG-11-00002, and the predecessor fund the Food Security and Crisis Mitigation II grant, award number EEM-G-00-0400013.

\section{References}

1. Leslie HM, Basurto X, Nenadovic M, Sievanen L,
Cavanaugh KC, Cota-Nieto JJ et al. Operationalizing the social-ecological systems framework to assess sustainability. Proceedings of the National Academy of Science 2015;112(19):5979-84.

2. Angelo D, Structure and evolution of the global seafood trade network, Environmental Research Letter 2015, 10.

3. FAO, FAO Fisheries \& Aquaculture - Fishing Gear Types - Ring nets, 2017.

4. Kittinger JN, Finkbeiner EM, Ban NC, Broad K, Carr $\mathrm{MH}$, Cinner JE et al. Emerging frontiers in socialecological systems research for sustainability of smallscale fisheries. Current Opinion Environmental Sustainability 2013;5(3-4):352-357.

5. Renner M. Aquaculture Continues to Gain on Wild Fish Capture, World watch institute 2014, 1-8.

6. Blythe JL. Resilience and social thresholds in small-scale fishing communities, Sustainability Science 2014;10(1):157-165.

7. Aguilera SE, Cole J, Finkbeiner EM, Le Cornu E, Ban NC, Carr MH et al. Managing Small-Scale Commercial Fisheries for Adaptive Capacity: Insights from Dynamic Social-Ecological Drivers of Change in Monterey Bay, PLoS One 2015, 1-22.

8. Ostrom E. Beyond markets and states: Polycentric governance of complex economic systems American Economic Association 2010;100(3):641-672.

9. Hardin G. The Tragedy of the Commons, Science New Series 1968;162(13):1243-1248.

10. Asare C, Okyere I. Profitability of Small-Scale Fisheries in Elmina, Ghana, Sustainability 2012, 2785-2794.

11. FAO. World fisheries and aquaculture in review 2018;35:3.

12. Béné $C$, Barange $M$, Subasinghe R, Pinstrup A, Merino G, Henre GI et al., Feeding 9 billion by 2050 -Putting fish back on the menu, Food Security 2015;7(2):261-274.

13. Brander K. Global fish production and climate change, PNAS 2007;104(50):44-46.

14. Wulandari D, Puspasari E, Yunikawati N, Soseco T, Narmaditya BS, Istiqomah $\mathrm{N}$ et al. Causes and Solutions of Tragedy of the Commons in natural resources management of Muncar coastal areas, International Journal of. Management and Business Research 2018;8(1):1-10.

15. Garcia SM, Rosenberg AA. Food security and marine capture fisheries: characteristics, trends, drivers and future perspectives, Philosophical Transactions of the Royal Society of London. Series B, Biological Science 2010;365(1554):2869-80.

16. Poteete AR, Janssen MA, Ostrom E. Working together: Collective action, the commons, and multiple methods in practice 2014, 1-346.

17. Hawkshaw RS, Sumaila UR. The tragedy of the tragedy of the commons: Why coining too good a phrase can be dangerous, Sustainability 2012;4(11):3141-3150.

18. Ostrom E. Governing the Commons, The Evolution of Institutions for Collective Action 1990, 302.

19. Ostrom E. A general framework for analyzing sustainability of social-ecological systems, Science New Series 2009;325(5939):419-422.

20. Partelow S. A review of the social-ecological systems framework: Applications, methods, modifications, and challenges, Ecology and Society 2018(23):4.

21. Phal-Wostl C. A conceptual framework for analysing adaptive capacity and multi-level learning processes in resource governance regimes, Global Environmental 
Change 2009;19(3):354-365.

22. McGinnis MD. Polycentric Governance in Theory and Practice: Dimensions of Aspiration and Practical Limitations 2016, 28.

23. Parente R, Pessoa P. Towards a Definition of Urban Polycentrism for Brazilian Metropolises, Delft university of Technology 2009, 1003-1014.

24. Araral E, Hartley C. Polycentric Governance for a New Environmental Regime: Theoretical Frontiers in Policy Reform and Public Administration. International Conference on Public Policy, Panel: Polycentric Policy and the Environment 2013, 1-31.

25. Blythe JL, Murray G, Flaherty MS. Historical perspectives and recent trends in the coastal Mozambican fishery, Ecology and Society 2013;18:4.

26. Delgado-Serrano M, Ramos PA. Making Ostrom's framework applicable to characterise social ecological systems at the local level, International. Journal of the Commons 2015;9:2.

27. Zealand A. Social - ecological inventory in a postdisaster context : the 2016 Kaik ō ura Social-ecological inventory in a postdisaster context : the 2016 Kaik o ura earthquake, Aotearoa-New Zealand 2019. Doi: 10.5751/ES-11075240309.

28. Cochran WG. Sampling techniques, New York: John Wiley and Sons 1977, 428.

29. Polonia G. Analysis of sample size in consumer surveys 2013, 6-8.

30. Thomsen I. Working Papers From the Central Bureau of Statistics of Norway the Use of Markov Chain Models 1976.

31. Fienberg S. Notes on Stratified Sampling, Statistics. 36303 Sampling Survey and Society 2003, 1-12.

32. Guwahat S. Chapter 2 Determination of appropriate Sample Size, Bulletin of the Gauhati University Mathematics Association International Journal of Applied Mathematics and Statistical Science 2013;12(1):28.

33. Nolinske T. Minimizing Error When Developing Questionnaires 1998.

34. Osuka K, Rosendo S, Riddell M, Huet J, Daide M, Chauque E et al. Applying a Social - Ecological Systems Approach to Understanding Local Marine Management Trajectories in Northern Mozambique, Sustainability 2020;12(3904-9):1-20.

35. Harper S, Grubb C, Stiles M, Sumaila UR. Contributions by Women to Fisheries Economies: Insights from Five Maritime Countries, Coastal Management 2017;45(2):91106.

36. Harper S, Zeller D, Hauzer M, Pauly D, Sumaila UR. Women and fisheries: Contribution to food security and local economies, Marine Policy 2013;39:56-63.

37. Glasgow T. Analysis of Profitability of Trawl Fleet, United Nation University Fisheries Training Program 2008.

38. Belhabib D, Subah Y, Broh N, Jusieh A, Nipey JN, Boeh WY, et al., Fisheries Centre on Liberian Fisheries from 1950, 2010-13.

39. Belhabib D, Mendy A, Subah Y, Broh N, Jusieh A, Nipeh JN et al., Fisheries catch under-reporting in The Gambia, Liberia and Namibia and the three large marine ecosystems which they represent, Environmental Development 2016;17:157-174.

40. Adriat A, Matic-Skoko S, Staglicic N, Kraljevic M,
Pallaoro A, Tutman P et al. Croatian artisanal fisheries and the state of it's littoral resources on the doorstep of entering the EU: effectiveness of conventional management and perspectives for the future 2011;52(1):87-100.

41. FAO. Code of Conduct for Responsible Fisheries, Food and Agriculture Organization of the United Nations 1995, 41. Doi: ISBN 92-5-103834-5.

42. Tomoko Yoshikawa KA. Entanglement of monofilament fishing lines and coral death, Biological Conservation 2004;117(5):557-560.

43. Onal H, Matlock GC. A Bioeconomic Analysis of the Texas Shrimp Fishery and Its Optimal Management, The American Journal of Agriculture Economics 1991;73:1161-1170.

44. Broadhurst MK, Sterling DJ, Millar RB. Configuring the mesh size, side taper and wing depth of penaeid trawls to reduce environmental impacts. PLoS One 2014;9(6):e99434.

45. Wolff M, Taylor MH, Tesfaye G. Implications of using small meshed gillnets for the sustainability of fish populations: A theoretical exploration based on three case studies, Fisheries Management and Ecology 2015;22(5):379-387.

46. Adeyeye SAO, Oyewole OB. An Overview of Traditional Fish Smoking In Africa, Journal of Culinary. Science amd Technology 2016;14(3):198-215.

47. Emere CM, Dibal M. A Survey of the Methods of Fish Processing and Preservation Employed By Artisanal Fishermen in Kaduna City, Food Science and Quality Management 2013;6088:16-23.

48. Olomola AS. Sources and resolution of conflicts in Nigerian artisanal fisheries, Society and Natural Resources 1998;11(2):121-135.

49. Ratner BD, Asgard B, Allison EH. Fishing for justice: Human rights, development, and fisheries sector reform, Global Environmental Change 2014;27(1):120-130.

50. Ostrom E. Governing the commons: the evolution of institutions for collective action," Natural Resource Journal 1990, 32.

51. Hauge K, Cleeland B, Wilson DC. Fisheries Depletion and Collapse Overview of the risk issue, 2009.

52. Wallner-Hahn S, Molander F, Gallordo G, Villasante S, Eklof S, Jiddawi NS et al., Destructive gear use in a tropical fishery: Institutional factors influencing the willingness-and capacity to change, Marine Policy 2016;72:199-210. 